\title{
Reproductive cycle of Tagelus plebeius (Mollusca: Bivalvia) in the estuary of the Cachoeira River, Ilhéus, Bahia, Brazil
}

\author{
Ceuta, LO.* and Boehs, G.* \\ Departamento de Ciências Biológicas, Universidade Estadual de Santa Cruz - UESC, Rod. Ilhéus-Itabuna, \\ Km 16, CEP 45662-900, Ilhéus, BA, Brazil \\ *e-mail: lilianeceuta@yahoo.com.br; gboehs@uesc.br
}

Received May 17, 2011 - Accepted September 19, 2011 - Distributed August 31, 2012

(With 6 figures)

\begin{abstract}
This study characterized the reproductive cycle of the stout razor clam Tagelus plebeius in the estuary of the Cachoeira River, Ilhéus, Bahia, northeastern Brazil. Samples of 20 animals per collection were taken biweekly from August 2005 to August 2006. The 480 specimens were measured on the antero-posterior axis (length) and then removed from the shell. After macroscopic analysis, the gonads were fixed in Davidson's solution, processed by routine histology and stained by Harris hematoxylin and eosin. The gonads of both males and females appeared milky white, without sexual dimorphism. Microscopic analyses indicated a M: F ratio of 1.06: 1 and continuous reproduction of T. plebeius in the region. The period from August to October showed the most intense spawning. This study provides another example of continuous reproduction of bivalves in tropical waters, and because this species is a heavily exploited fishery resource in the region, it draws attention to the need for a management plan aimed at reducing harvests.
\end{abstract}

Keyworks: fishery resource, reproductive cycle, stout razor clam.

\section{Ciclo reprodutivo de Tagelus plebeius (Mollusca: Bivalvia) no estuário do Rio Cachoeira, Ilhéus-Bahia, Brasil}

\begin{abstract}
Resumo
Neste estudo, objetivou-se caracterizar o ciclo reprodutivo de Tagelus plebeius na região estuarina do Rio Cachoeira, Ilhéus-Bahia. As amostragens, 20 animais/coleta, foram feitas quinzenalmente, entre agosto de 2005 e agosto de 2006. Os 480 animais, depois de medidos quanto ao seu eixo ântero-posterior (comprimento), foram removidos da concha e, após análise macroscópica, as gônadas foram fixadas em solução de Davidson, processadas por técnica rotineira de histologia e coradas com hematoxilina de Harris e eosina. As gônadas de machos e fêmeas apresentaram aspecto branco leitoso e não houve dimorfismo sexual. As análises microscópicas evidenciaram razão sexual M:F de 1,06:1 e reprodução contínua de $T$. plebeius na região. O período entre agosto e outubro foi caracterizado como o de maior eliminação de gametas. $\mathrm{O}$ estudo fornece outro exemplo de reprodução contínua de bivalves em regiões tropicais e, por ser um recurso pesqueiro intensamente explorado na região, chama a atenção para a criação de um plano de manejo que vise à redução de sua coleta.
\end{abstract}

Palavras-chave: recurso pesqueiro, ciclo reprodutivo, unha-de-velho. 


\section{Introduction}

Studies on the reproduction of a species of mollusk are important to understand its life history and problems of regulation and conservation (Quayle, 1943). According to Coe (1943), bivalve mollusks have a wide variety of reproductive strategies, and studies of reproduction in this group can provide important knowledge of sexuality. Additionally, knowledge of the periods of greatest reproductive activity is essential to establish management plans for the repopulation of wild stocks (Galvão et al., 2006). Information on the reproductive cycle also makes it possible to know the optimum periods for the placement of seed collectors for aquaculture (Nascimento and Lunetta, 1978; Galvão et al., 2006).

In Brazil, studies on the reproduction of bivalves are relatively few. Information is available for Donax hanleyanus Philippi, 1847 (Gil and Tomé, 2004a), Chione pubera (Bory Saint-Vicent, 1827) (Borzone et al., 2001), Perna perna (Linnaeus, 1758) (Galvão et al., 2006), Anomalocardia brasiliana (Gmelin, 1791) (Narchi, 1976; Grotta and Lunetta, 1980; Barreira and Araújo, 2005; Luz and Boehs, 2011) and Crassostrea rhizophorae (Guilding, 1828) (Nascimento and Lunetta, 1978; Nascimento et al., 1980; Lenz and Boehs, 2011).

The stout razor clam Tagelus plebeius (Lightfoot, 1786) (Psammobiidae) is used for food, especially by people living along the coast (Ceuta et al., 2010) and has a potential for aquaculture (Cledón et al., 2004). This bivalve inhabits sandy-muddy sediment banks in estuaries and occurs from North Carolina to Florida and Texas, the West Indies, Venezuela, Surinam, and Brazil to southern Argentina (Rios, 2009). Despite the economic interest of T. plebeius, studies on the reproduction of this species are few. In Brazil, Matos et al. (1997) described aspects of the structure of the spermatozoa, and Ceuta et al. (2010) recorded occasional hermaphroditism in this species. Cledón et al. (2004) studied the reproductive cycle of T. plebeius in Argentina. The present study is the first report on the reproductive cycle of $T$. plebeius on the Brazilian coast.

In the estuary of the Cachoeira River on the southern coast of the state of Bahia, Brazil, several species of mollusks, including oysters, mussels and clams are exploited by traditional communities (Pinto and Boehs, 2008). To date only the reproductive cycle of A. brasiliana has been studied in this region (Luz and Boehs, 2011). Tagelus plebeius is concentrated mainly at a site called "Coroa do Meio", where it forms a bank and where it is harvested daily (Ramos, 2002) by people living nearby, with no management or tracking of the stock. According to Schiavetti et al. (2002), the estuary is moderately polluted by domestic waste and heavy metals derived from agricultural activities in the region. In the present study, we aimed to obtain information on the reproductive cycle of T. plebeius in this estuary, identifying periods of increased reproductive activity. These data may support a future management plan, aiming toward the sustainability of this fishery resource in the region.

\section{Material and Methods}

The estuary of the Cachoeira River lies in southern Bahia (14 ${ }^{\circ} 46^{\prime}-14^{\circ} 50^{\prime} \mathrm{S}$ and $\left.39^{\circ} 05^{\prime}-39^{\circ} 01^{\prime} \mathrm{W}\right)$. It is formed by the Cachoeira, Santana, and Fundão rivers, and the city of Ilhéus extends along its shores (Schiavetti et al., 2002). The collections were made on a shallow tidal flat, known as "Coroa do Meio" (14 46' 30' $\mathrm{S}$ and 39 03' 20 ', W), with an area of approximately $0.28 \mathrm{~km}^{2}$ during low tide. The animals were collected randomly, during low tide, with the aid of a shovel. Their locations were identified by the siphon holes in the sand. 20 animals were collected biweekly between August 2005 and August 2006. Temperature and salinity were also measured randomly within the site of each collection of biological material, by means of a standard mercury thermometer and an Atago S/Mill manual optical refractometer. Rainfall data from this period were obtained, only for monthly intervals, from the Executive Commission Plan of Cocoa Farming (CEPLAC) in Ilhéus.

In the laboratory, the animals were measured on the antero-posterior axis (length) with a manual caliper. We used animals with a length between 36.5 and $68.3 \mathrm{~mm}$ (mean $53.2 \mathrm{~mm}, \pm 6.66 \mathrm{SD}, \mathrm{n}=480$ ). Based on preliminary microscopic analysis, animals in this size range are sexually mature. After macroscopic analysis, the clams were opened and the gonads separated with a scalpel. These were fixed in Davidson's solution (Shaw and Battle, 1957) for 24 hours and then preserved in $70 \%$ ethanol, after which they were subjected to routine histology, comprising: dehydration in an ethanol series (70-100\%), clearing in xylene, embedding in paraffin, cutting in $7-\mu \mathrm{m}$ thick sections using a microtome, and staining with Harris hematoxylin and eosin (H\&E). The slides were examined under a light microscope. Stages of gonadal development were classified according to the appearance of follicles and the amount of interfollicular tissue and germ cells: stem cells, oogonia, basophil oocytes, in pre-vitellogenic and vitellogenic stages and mature oocytes for females; and spermatogonia, spermatocytes, spermatids, and spermatozoa in males. The classification of gonadal stages was adapted from a study by Grotta and Lunetta (1980). The Chi-square $\left(\chi^{2}\right)$ test was used to assess significant differences in sex ratio. The first half of each month is referred to as "I" and the second as "II."

\section{Results}

\subsection{Abiotic factors}

The water temperature ranged from 24 (May I, June II and July I) to $30.5{ }^{\circ} \mathrm{C}$ (April I) (mean 27.2 \pm 1.9 SD, $\mathrm{N}=25$ ) (Figure 1). Salinity ranged from zero (August I, December I and II, April II and June II) to 23 (March I) (mean 11, \pm 7.37 SD, $\mathrm{N}=25$ ) (Figure 1). The highest rainfall occurred in December and June (248.8 and $228.8 \mathrm{~mm}$, 


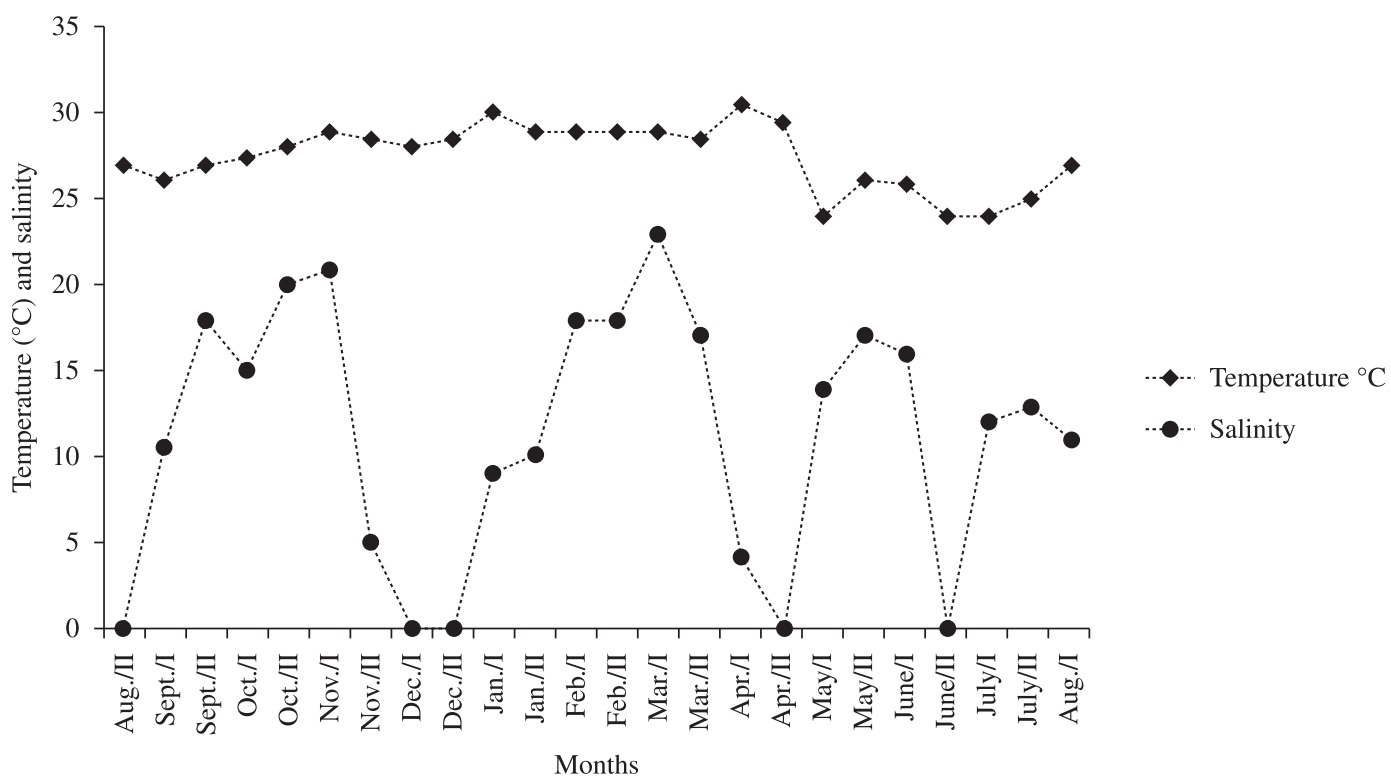

Figure 1. Biweekly values of water temperature $\left({ }^{\circ} \mathrm{C}\right)$ and salinity at Coroa do Meio, Cachoeira River estuary (Ilhéus, Bahia, Brazil), from August 2005 through August 2006.

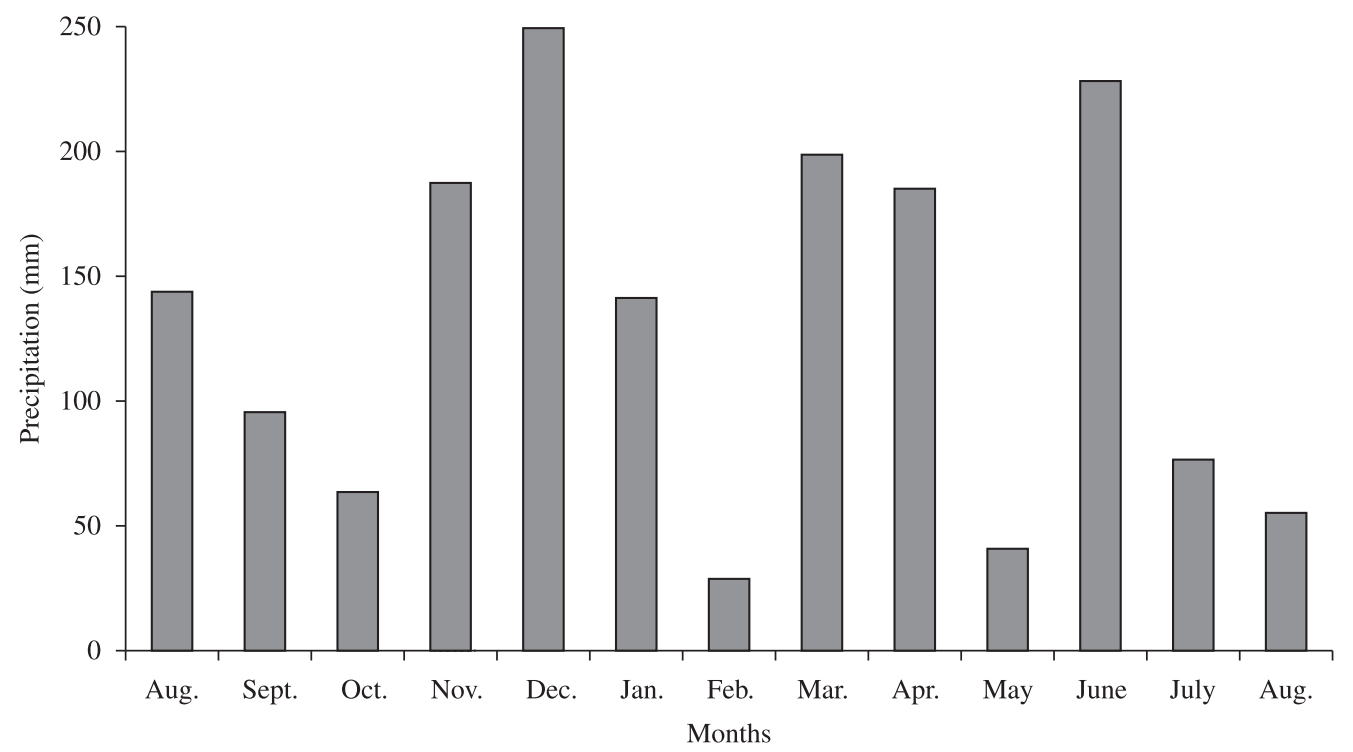

Figure 2. Monthly rainfall in Ilhéus (Bahia, Brazil), from August 2005 through August 2006.

respectively), and the lowest in February $(28.3 \mathrm{~mm})$ and May (40.6 mm) (Figure 2).

\subsection{Sexual dimorphism and sex ratio}

The gonads of both males and females appeared milky white. Sexual dimorphism was not observed. Microscopic analysis showed 235 males (M) (50.43\%) and 229 females (F) $(49.14 \%)$, with an M: F ratio of 1.06:1. The proportion of males and females was similar $(p>0.05)$ throughout the study period. Two cases of hermaphroditism $(0.43 \%)$ were observed, with female follicles predominating over males.

\subsection{Gonadal stages}

The process of gametogenesis was continuous and was observed at all stages. Four stages of gonadal maturation were observed in females: Maximum Maturation and Spawning (MS), Advanced Spawning (AS), Recovery (R), and Total Spawning (TS). In the MS stages, the follicles were expanded, juxtaposed (with little interfollicular tissue) and with thin walls. At this stage, germ cells were observed attached to the walls at different stages of follicular maturation; oocytes in vitellogenesis predominated; and 
mature oocytes were present free in the follicular lumen (Figures 3a, b). Even at this stage, oocytes were seen scattered in the lumen of the follicles and these empty spaces in the center, indicating spawning. In AS most of the mature oocytes were spawning, and the wall thickness of the follicle and the number of germ cells increased. In AS, intra- and interfollicular spaces, as well as interfollicular tissue also increased (Figures 3c, d). The R stage was featured as a non-spawning phase in the female. At this stage, residual oocytes were seen in the center of the follicles, and a high activity of maturation of germ cells (stem cells, oogonia, basophilic oocytes and in pre-vitellogenesis), predominantly basophilic oocytes; and again, the follicles were decreased in size and thick-walled, and interfollicular tissue was visible in larger quantities (Figures 3e, f). The TS stage was characterized by a reduction in the number and size of follicles and the conspicuous presence of interfollicular tissue. At this stage, mature oocytes were present in the lumen of the follicle and some germ cells were attached to the wall of the follicle (Figures $3 \mathrm{~g}, \mathrm{~h}$ ).

In males, three stages of gonadal maturation were identified: Maximum Maturation and Spawning (MS),
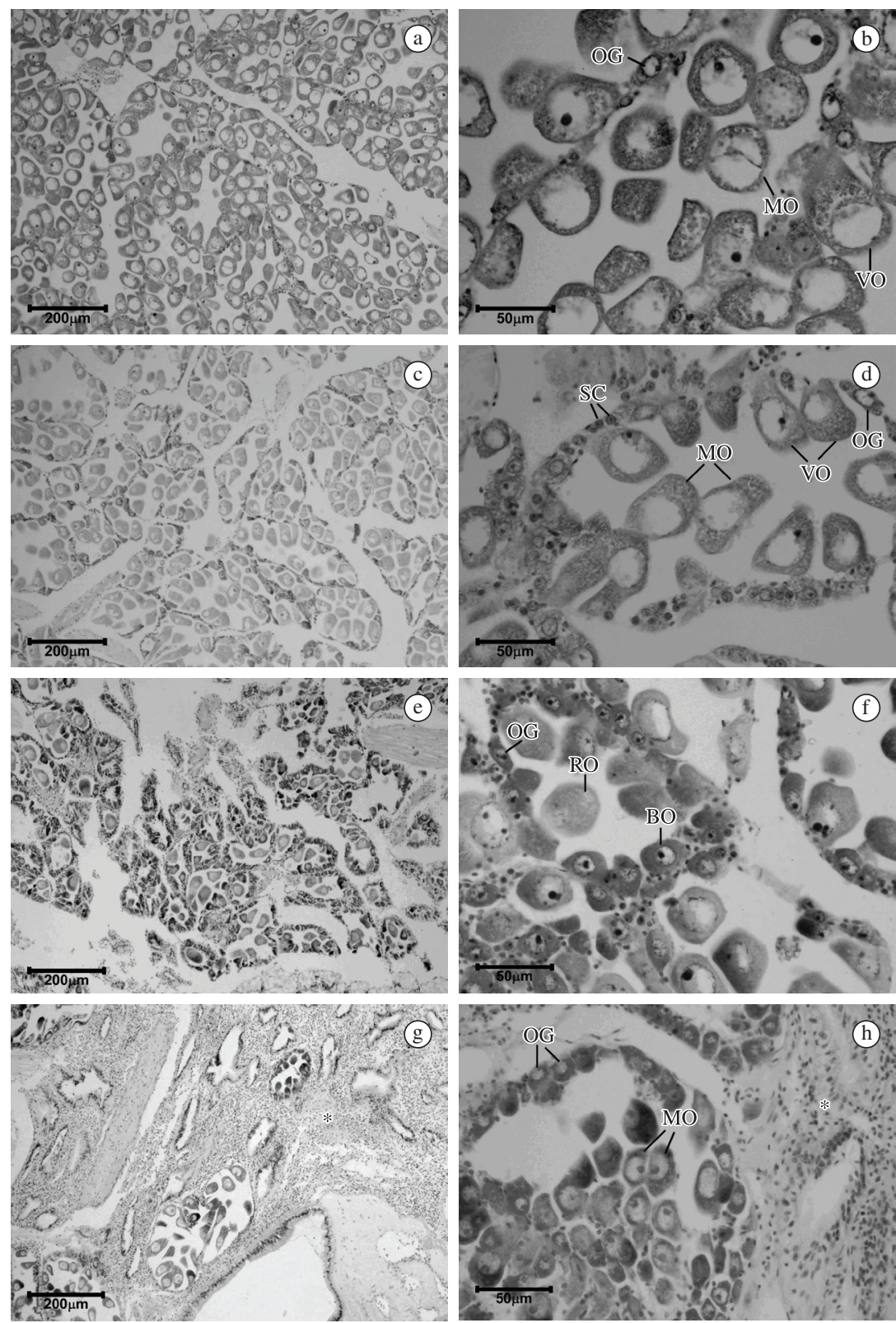

Figure 3. Female gonads of Tagelus plebeius, Cachoeira River estuary (Ilhéus, Bahia, Brazil) in different stages of maturation: a and b) Maximum Maturation and Spawning; c and d) Advanced Spawning; e and f) Recovery; g and h) Total Spawning. $\mathrm{BO}=$ Basophilic Oocyte; $\mathrm{MO}=$ Mature Oocyte $; \mathrm{OG}=$ Oogonia; $\mathrm{RO}=$ Residual Oocyte; $\mathrm{SC}=$ Stem Cells; $\mathrm{VO}=$ Vitellogenic Oocyte; * = interfollicular tissue. 
Advanced Spawning (AS) and Total Spawning (TS). In the MS stage, the follicles were filled, expanded and juxtaposed and no interfollicular tissue was observed. Next to the wall, there was a thin layer of germ cells and spermatogonia, and toward the center of the follicle were spermatocytes and spermatids. The sperm in this stage were found in the lumen of the follicle. Spawning was perceived by the small space inside the follicle (Figures $4 \mathrm{a}, \mathrm{b}$ ). In AS, most of the sperm was eliminated having a consequent increase in space within and between the follicles. The layer of germ cells increased, and there was a slight reduction in the size of follicles (Figures 4c, d). In stage TS, the follicles were reduced in size and in number. Next to the wall, some cells in maturation were present. The sperm cells were scattered in the lumen of the follicle and interfollicular tissue was present, although in small amounts (Figures 4e, f). Unlike females, males did not show the recovery stage, with spawning being continuous.

Both females and males were undergoing gametogenesis and spawning throughout the period, showing continuous reproduction with no rest period. The peaks of spawning were characterized by a predominance of individuals in stage MS. For females, the first peak occurred in late winter and early spring (August II to October I), when $70 \%$ of
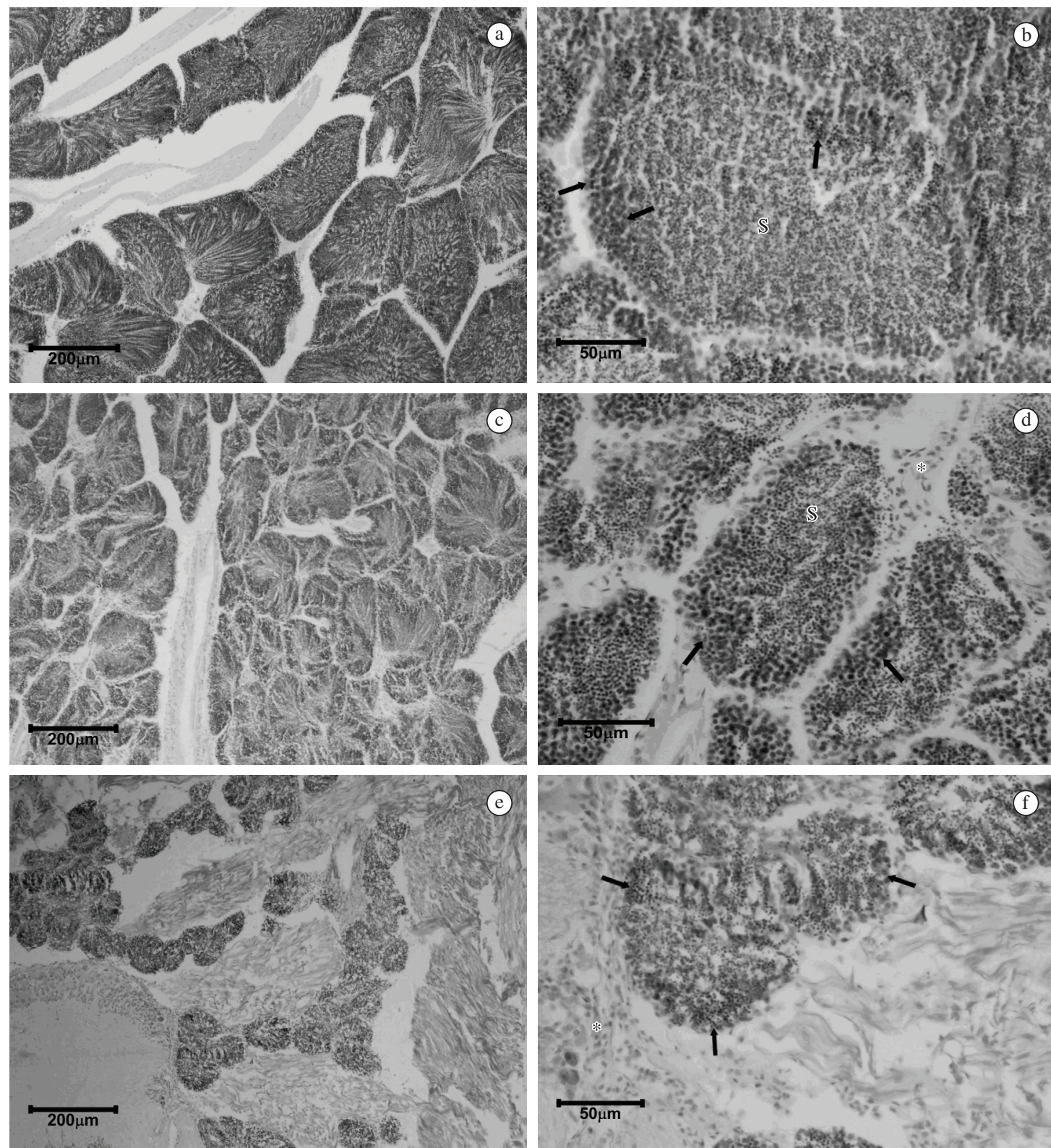

Figure 4. Male gonad of Tagelus plebeius, Cachoeira River estuary (Ilhéus, Bahia, Brazil) in different stages of maturation: a and b) Maximum Maturation and Spawning; c and d) Advanced Spawning; e and f) Total Spawning. S = Spermatozoa; arrows = germ cell; $*$ = interfollicular tissue. 
them were in MS (Figure 5), and lasted longest. Other, briefer peaks occurred in December I (late spring), March II (late summer) and June II and July II (winter). The AS stage lasted practically the whole period, and was more frequent in September II (73\%) and July I (91\%). After the first peak of spawning, most females were in the R stage (October II and November I and II). The same occurred in summer (December II, January II, February I and II and March I), after two short peaks of spawning, and in autumn (April I and II and May I and II and June I), also after a peak of spawning. Females in stage TS were infrequent, observed in only six samples and comprising only $3.5 \%$ of the females analyzed (Figure 5).

Most males analyzed were at stage MS or AS (Figure 6). For them, the longest peak occurred in August I through October I (late winter and early spring), and briefer peaks in December I (spring), January I (summer), March II and April I (autumn) and June II (early winter). All peak spawning periods of males coincided with those of females, except for peaks in January I and April I. Males in stage AS were more frequent in spring (October II and November I and II), autumn (May II and June I) and winter (July II and August II).

\section{Discussion}

The data from this study indicated that Tagelus plebeius reproduces continuously in the Cachoeira River estuary, with simultaneous gametogenesis and spawning. In the Brazilian northeast, this pattern was also observed in the bivalve A. brasiliana (Grotta and Lunetta, 1980; Barreira and Araújo, 2005; Luz and Boehs, 2011). Probably this is determined by the small amplitude of seasonal temperature variation in tropical regions. According to Loosanoff and Davis (1952) and Lubet (1959), temperature seems to be the main factor triggering reproductive events in marine bivalves, and is also responsible for the synchronization of the breeding season. Unlike tropical regions (as in this study), at higher latitudes bivalves tend to have resting periods between reproductive events. In southern Brazil, C. pubera showed peaks of spawning related to temperature increases, and gonadal reversal coinciding with the lowest temperatures of the year (Borzone et al., 2001). Gil and Tomé (2004a), also in southern Brazil, reported that a higher percentage of $D$. hanleyanus release gametes in the warmer months. Cledón et al. (2004), studying the reproductive cycle of T. plebeius in Argentina, observed that populations from different locations may show changes in reproductive strategies, which are in turn influenced by environmental factors, mainly by temperature; and that these differences were more significant when comparing populations from different latitudes.

Salinity and rainfall can also influence the reproduction of marine bivalves. According to the review by Sastry (1979), reproduction in at least some species is correlated with these factors. The decrease in salinity causes osmotic stress, which in turn can stimulate the release of gametes (Luz and Boehs, 2011). Lunetta and Grotta (1982) found that when bivalves are near the limits of osmotic tolerance,

$\begin{array}{lllllllllll}13 & 12 & 11 & 11 & 6 & 8 & 10 & 12 & 10 & 8 & 8\end{array}$

$\begin{array}{llllllllllll}8 & 11 & 12 & 5 & 3 & 10 & 12 & 8 & 10 & 11 & 11 & 9\end{array}$

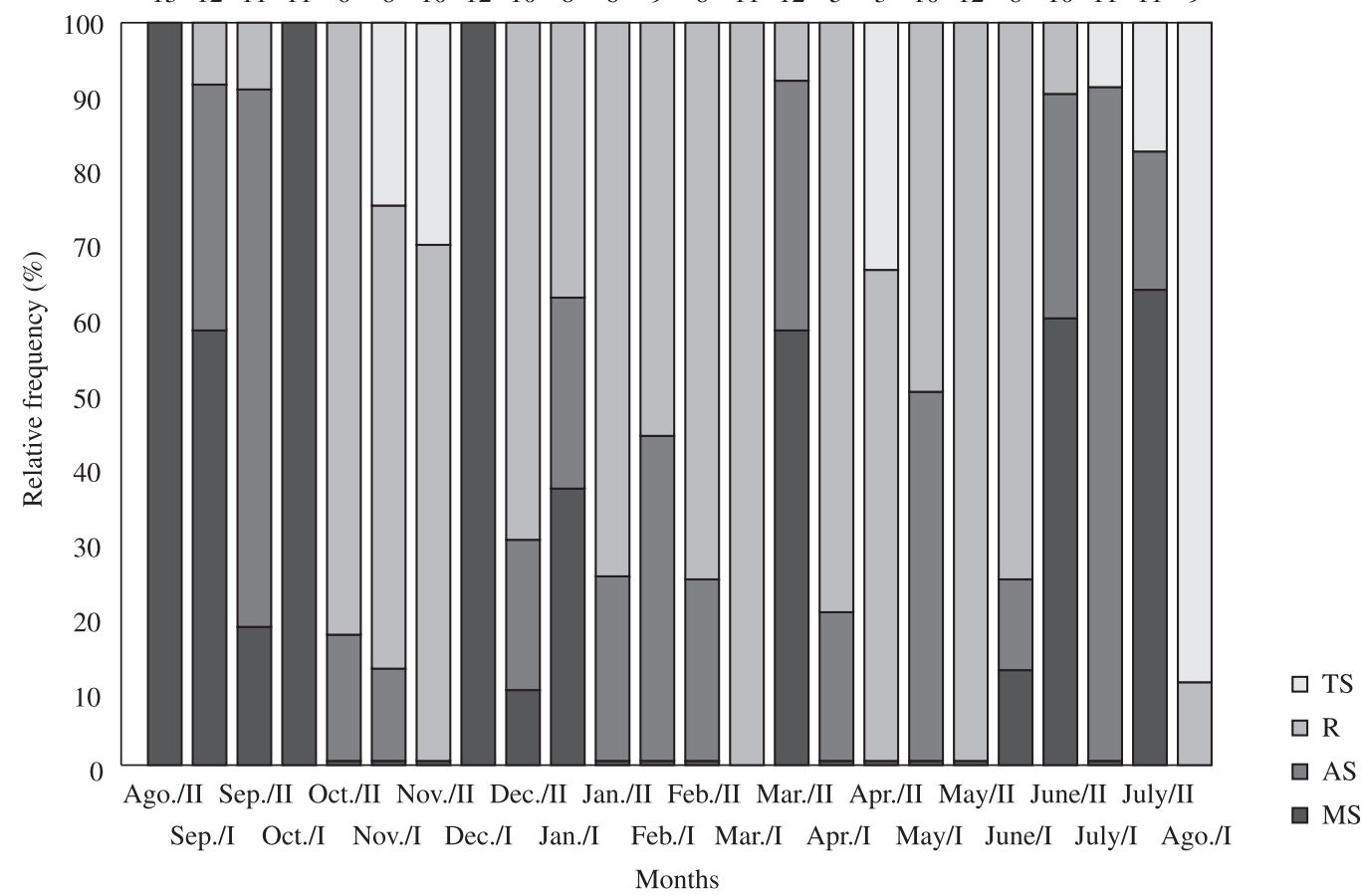

Figure 5. Relative frequency of stages of the reproductive cycle of female Tagelus plebeius from August 2005 to August 2006 in the Cachoeira River estuary (Ilhéus, Bahia, Brazil). MS = Maximum Maturation and Spawning; AS = Advanced Spawning, R = Recovery; TS = Total Spawning. 


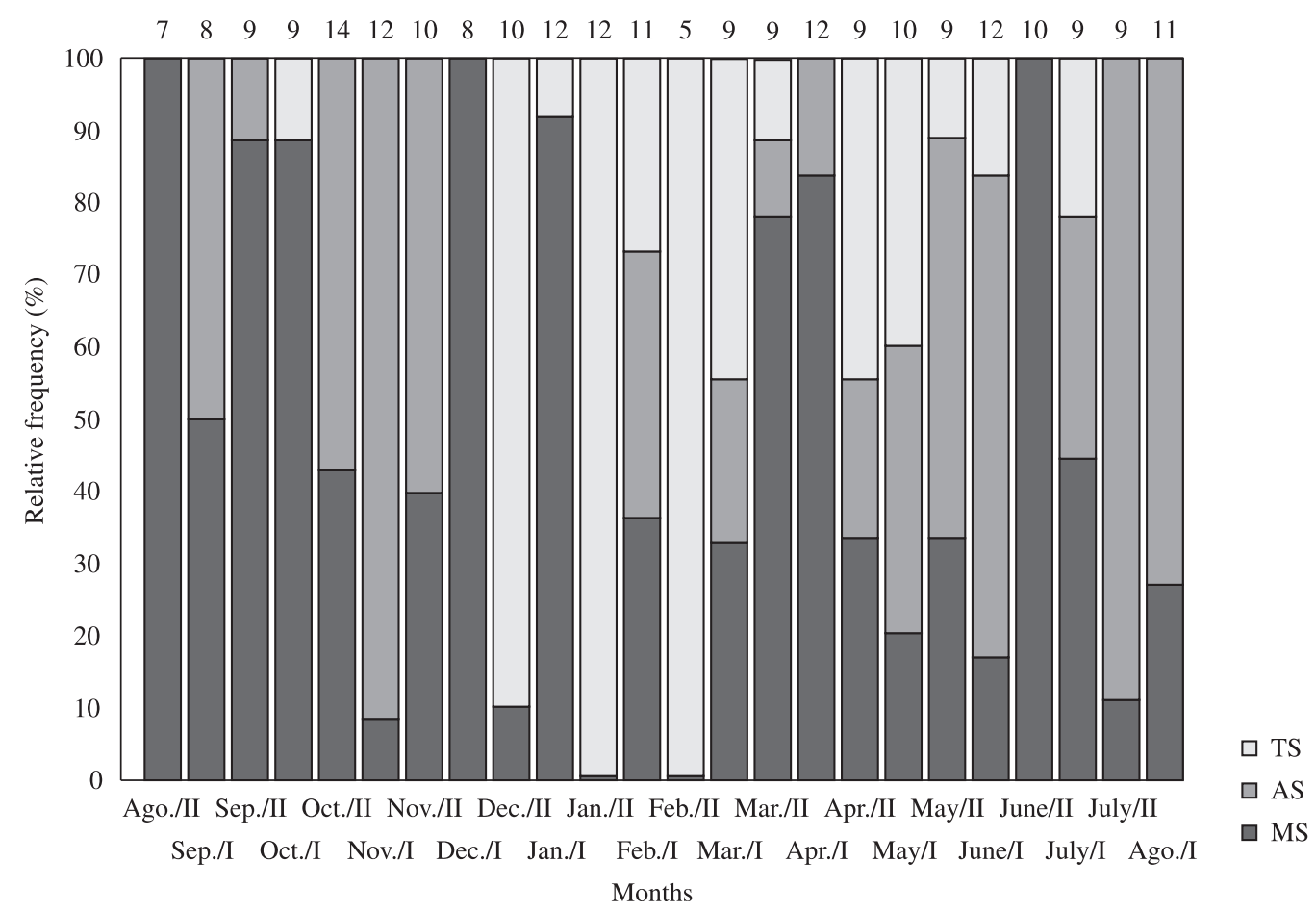

Figure 6. Relative frequency of stages of the reproductive cycle of male Tagelus plebeius from August 2005 through August 2006 in the Cachoeira River estuary (Ilhéus, Bahia, Brazil). MS = Maximum Maturation and Spawning; AS = Advanced Spawning; TS = Total Spawning.

they close their valves, reducing filtration and feeding rates, which could affect gametogenesis. For T. plebeius in the Cachoeira River estuary, at least for males, there seems to be a positive correlation between the maximum maturation and spawning stage (MS) and rainfall. In some months of high rainfall (above $180 \mathrm{~mm}$, in December, March, April and June) the frequency of males in the MS stage was high. However, further studies are needed to confirm this correlation. For the same estuary and same period as this study, Luz and Boehs (2011) also found a coincidence between the intensification of total release of gametes (especially in females) and higher rainfall in A. brasiliana.

With regards to synchronism between males and females, the spawning peaks for both sexes were coincident, showing that there is synchrony in the release of oocytes and sperm in T. plebeius in the Cachoeira River. However, peaks of more intense spawning in females were less frequent, as well as lasting for shorter periods than in males. For the oyster $C$. rhizophorae, Nascimento and Lunetta (1978) found that males recovered and matured faster than females. We agree with the interpretation of these authors, that oogenesis requires more time and more energy, due to the need for yolk production in females. This explains the finding, in the present study of the differences in the gametogenic cycle between males and females, in the frequency and duration of spawning, as well as in the existence of the recovery stage in females. After the main peaks of spawning for females, most of these were found in the recovery stage $(\mathrm{R})$, indicating that after these spawning peaks, the follicles remain in the gonad and continue to produce new gametes. At the total spawning stage (TS), a reduction in the size and number of follicles and the large amount of interfollicular space indicate that at this stage, probably the gonadal tissue is reabsorbed to form new follicles. Thus, because of these features of the TS stage and its low frequency over the period studied, it is likely that this stage occurs only after the successive processes of maturation, emptying, and recovery.

Hermaphroditism was observed in low frequency in this population. Ceuta et al. (2010) suggested that this phenomenon, also observed in Iphigenia brasiliana (Lamarck, 1818) in the same estuary, may be related to the wide local variations in salinity, and to pollution effects. Bivalves are predominantly dioecious, but can show occasional hermaphroditism. Coe (1943) and Heller (1993) noted that occasional flaws in the mechanism of sexual differentiation, or parasitism may cause hermaphroditism.

This study found an approximately equal sex ratio in agreement with observations by Cledón et al. (2004) for T. plebeius, for A. brasiliana by Grotta and Lunetta (1980), for D. hanleyanus by Gil and Tomé (2004b), and also, as reviewed by Coe (1943), for other bivalve species.

The present study provides new information on the reproductive cycle of $T$. plebeius from Brazil, and also another example of continuous reproduction of bivalves in tropical waters. Continuous reproduction of the stout razor clam in the Cachoeira River population promotes constant renewal of the natural stock, allowing, in principle, 
exploitation of this bivalve throughout the year. However, because the clams are harvested without any control, a management plan is needed to assure the conservation of the species in the region. This plan could include the creation of a closed season during the months of high gamete release (August-October), as well as restricting the collection of small-sized clams throughout the year.

Acknowledgments - To CAPES for financial support, CEPLAC for providing the rainfall data. We would also like to thank Rui R. Cavalcante, Leandro S. Oliveira and William C. T. Tonini for their support in collecting, and Thiago R. Pinto for his assistance in processing samples.

\section{References}

BARREIRA, CAR. and ARAÚJO, MLR., 2005. Ciclo Reprodutivo de Anomalocardia brasiliana (Gmelin, 1791) (Mollusca, Bivalvia, Veneridae) na Praia do Canto da Barra, Fortim, Ceará, Brasil. Boletim do Instituto de Pesca, vol. 1, no. 31, p. 9-20.

BORZONE, CA., VARGAS, KM., PEZZUTO, PR. and TAVARES, YAG., 2001. Aspectos Reprodutivos e Dinâmica Populacional de Chione pubera (Bory Saint-Vincent) (Bivalvia, Veneridae) no Sul do Brasil. Revista Brasileira de Zoologia, vol. 2, no. 18, p. 333-349.

CEUTA, LO., BOEHS, G. and SANTOS, JJB., 2010. Hermaphroditism among dioecious Tagelus plebeius (Lightfoot, 1786) (Mollusca, Psammobiidae) and Iphigenia brasiliana (Lamarck, 1818) (Mollusca, Donacidae) on the Cachoeira River Estuary, Ilhéus, Bahia, Brazil. Brazilian Journal of Biology, vol. 70, p. 125-127. PMid:20231968.

CLEDÓN, M., BRICHTOVA, ACP., GUTIÉRREZ, JL. and PENHASZADEH, PE., 2004. Reproductive cycle of the stout razor clam, Tagelus plebeius (Lightfoot, 1786), in the Mar Chiquita coastal lagoon, Argentina. Journal of Shellfish Research, vol. 23, no. 2 , p. 443-446.

COE, WR., 1943. Sexual differentiation in mollusks. I. Pelecypods. The Quartely Review of Biology, vol. 18, p. 154-164. http://dx.doi. org/10.1086/394673

GALVÃO, MSN., HENRIQUES, MB., PEREIRA OM. and MARQUES, HA., 2006. Ciclo reprodutivo e infestação parasitária de mexilhões Perna perna (Linnaeus, 1758). Boletim do Instituto de Pesca, vol. 32, p. 59-71.

GIL, GM. and TOMÉ, JW., 2004a. Descrição do ciclo reprodutivo de Donax hanleyanus (Bivalvia, Donacidae) no sul do Brasil. Iheringia. Série Zoológica, vol. 94, no. 3, p. 271-276.

-, 2004b. Proporção sexual e comprimento de concha na primeira maturação sexual em Donax hanleyanus (Bivalvia: Donacidae) no Rio Grande do Sul, Brasil. Revista Brasileira de Zoologia, vol. 21 , no. 2 , p. 345-350. http://dx.doi.org/10.1590/S010181752004000200032

GROTTA, M. and LUNETTA, JE., 1980. Ciclo Sexual de Anomalocardia brasiliana (Gmelin, 1791) do Litoral do Estado da Paraíba. Revista Nordestina de Biologia, vol. 1, no. 3, p. 5-55.

HELLER, J., 1993. Hermaphroditism in molluscs. Biological Journal of the Linnean Society, vol. 48, p. 19-42. http://dx.doi. org/10.1111/j.1095-8312.1993.tb00874.x

LENZ, TM and BOEHS, G., 2011. Ciclo reproductivo del ostión de manglar Crassostrea rhizophorae (Bivalvia: Ostreidade) en la Bahía de Camamu, Bahia, Brasil. Revista de Biología Tropical, vol. 59, p. 137-149. PMid:21516642.
LOOSANOFF, VL. and DAVIS, HC., 1952. Temperature requirements for maturation of gonads of northern oysters. Biological Bulletin, vol. 103, p. 80-96. http://dx.doi.org/10.2307/1538408

LUBET, P., 1959. Recherches sur le cycle sexuel et l'emission des gamètes chez les Mytiloidae et les Pectinidae (mollusques bivalves). Revue des Travaux de l'Institut Scientifique des Pêches Maritimes, vol. 23, p. 387-548.

LUNETTA, JE. and GROTTA, M., 1982. Influência de fatores exógenos e endógenos sobre a reprodução de moluscos marinhos. Boletim de Fisiologia Animal, vol. 6, p. 191-204.

LUZ, JR. and BOEHS, G., 2011. Reproductive cycle of Anomalocardia brasiliana (Mollusca: Bivalvia: Veneridae) in the estuary of the Cachoeira River, Ilhéus, Bahia. Brazilian Journal of Biology, vol. 71, no. 3, p. 1-8. http://dx.doi.org/10.1590/ S1519-69842011000400012

MATOS, E., MATOS P., CASAL, G. and AZEVEDO, C., 1997. Estrutura fina do espermatozóide de Tagelus plebeius (Lightfoot) (Mollusca, Bivalvia) do litoral norte do Brasil. Revista Brasileira de Zoologia, vol. 14, no. 3, p. 595-600. http://dx.doi.org/10.1590/ S0101-81751997000300010

NARCHI, W., 1976. Ciclo anual de gametogênese de Anomalocardia brasiliana (Gmelin, 1791) (Mollusca, Bivalvia). Boletim de Zoologia da Universidade de São Paulo, vol. 1, p. 331-350.

NASCIMENTO, IA. and LUNETTA, JE., 1978. Ciclo sexual da ostra de mangue e sua importância para o cultivo. Ciência e cultura, vol. 36 , no. 6, p. 736-742.

NASCIMENTO, IA., SILVA, EM., RAMOS, MIS. and SANTOS, AE., 1980. Desenvolvimento da gônada primária em ostras de mangue Crassostrea rhizophorae: idade e tamanho mínimos de maturação sexual. Boletim de Fisiologia Animal, vol. 2, p. 63-93.

PINTO, TR. and BOEHS, G., 2008. Nematopsis sp. (Apicomplexa: Eugregarinida) em Mytella guyanensis (Lamarck, 1819) (Bivalvia: Mytilidae) da Região Estuarina do Rio Cachoeira, Ilhéus, Bahia, Brasil. Brazilian Journal of Veterinary Research and Animal Science, vol. 45, no. 2, p. 95-100.

QUAYLE, DB., 1943. Sex, gonad development and seasonal gonad changes in Paphia staminea Conrad. Journal of the Fisheries Research Board of Canada, vol. 6, p. 140-151.

RAMOS, S., 2002. Exploração do moapen Tagelus plebeius (Lightfoot, 1786) (Mollusca: Pelecypoda) no Estuário do Rio Cachoeira: estratégia de sobrevivência humana e valorização da seção estuarina de Ilhéus. Bahia. Ilhéus: Universidade Estadual de Santa Cruz. 125 p. Dissertação de Mestrado em Desenvolvimento Regional e Meio Ambiente.

RIOS, EC., 2009. Compendium of Brazilian Sea shells. Rio Grande: Evangraf. 676 p.

SASTRY, AN., 1979. Pelecypoda (Excluding Ostreidae). In GIESE, A. and PEARSE, JS. (Eds.). Reproduction of Marine Invertebrate. New York: Academic Press. vol. 5, p. 113-292.

SCHIAVETTI, A., SCHILLING, AC. and DE OLIVEIRA, HT., 2002. Caracterização Sócio-ambiental da Bacia Hidrográfica do Rio Cachoeira, Sul da Bahia, Brasil. In SCHIAVETTI, A. and CAMARGO, AFM. (Eds.). Conceitos de Bacias Hidrográficas: teoria e aplicações. Ilhéus: Editus. 289 p.

SHAW, BL. and BATTLE, HI., 1957. The gross and microscopic anatomy of the digestive tract of the oyster Crassostrea virginica (Gmelin). Canadian Journal of Zoology, vol. 35, p. 325-347. http://dx.doi.org/10.1139/z57-026 